\title{
Comparison of Zinc Roofed House Temperature Distribution between Open Water Exhausted With Radiator Cooling System
}

\author{
Rosdi Ab Rahman ${ }^{1, a}$, Masiri Kaamin 2,b ${ }^{2}$ Mahmod Abd Hakim Mohamad ${ }^{3, c}$, \\ Azizul Rahman Abd Aziz ${ }^{4, \mathrm{~d}}$ and Mohd Hadri Mohamed Nor ${ }^{5, \mathrm{e}}$ \\ 1,2,3,4,5 Pusat Pengajian Diploma, Universiti Tun Hussein Onn Malaysia, 86400 Parit Raja, Batu \\ Pahat, Johor. \\ arosdi@uthm.edu.my, ${ }^{b}$ masiri@uthm.edu.my, ${ }^{c}$ hakim@uthm.edu.my, \\ dazizulaz@uthm.edu.my, ${ }^{\mathrm{e}}$ hadri@uthm.edu.my
}

Keywords: Thermal comfort, Cooling systems, Water circulation, Airflow, Radiator, Heat transfer.

\begin{abstract}
Thermal condition of a house is one of the comfort factors. Traditionally, village houses in Malaysia uses corrugated zinc roofing due to economic reason. Considering the thermal conductivities of the material, space under the roof coverage will intent to occur thermal discomfort due to Malaysian ambient temperature. The roof plays an important role to ensure the house is in a state insulated from the hot sun and rain where the zinc roofing will radiated by the sun in noon and yet become the heat source for in-house area. Thermal discomfort will result due to zinc highly heat absorbing material property. The space under the covering will experience significant temperature increase proportional to the amount of supplied heat from sunlight radiated to the zinc roof, and will further be aggravated if ventilation is poor. The purpose of this study is to compare the temperature distribution by two alternatives methods to reduce the temperature inside a zinc-covered house. The main concept of this cooling system is by splashing water throughout the area of the zinc roofing, where heat exchange process will occur upon contact. The process will dissipate heat from the zinc and will increase the water temperature. This research is focusing on the medium (water) re-cooling process by either open water exhausted or radiator system to state that which one will give better heat exchange. Open water exhausted system heated water will then free fall by gravity into a tank through perforated tube as water droplets. To facilitate higher rate of water-cooling, fan will be provided. Another re-cooling system is the radiator system, which use radiator device to cool down the heated water. Radiator use coolant as the medium to exchange the heat from the roof heated water. By the same heat transfer process, the circulated water temperature will be lower where, which will be recirculation back to the roof. Both systems had been compared about the differences of temperature drop distribution which result the better water re-cooling system.
\end{abstract}

\section{Introduction}

Thermal comfort as defined by ASHRAE Standard 55 is that condition of mind which expresses satisfaction with the thermal environment. In other words, it describes a person's psychological state of mind and is usually referred to in terms of whether someone is feeling too hot or too cold. In controlling the thermal comfort to some acceptable level, an alternative cost effective cooling system for corrugated zinc roofing is develop, using circulated water as cooling agent.

The corrugated zinc sheet is one of the popular methods used to make roofing for majority of dwellers in traditional Malay rural community as it has the advantage of being cost effective where it is cheaper, easy to construct and durable [11]. However, it also has its own drawback when thermal comfort in the living space covered by the roof is sacrificed. This happens because zinc will efficiently absorb thermal radiation from sunlight and then radiates it down into the living space. [12]. This problem will strengthen if the house does not have proper ventilation as the heat will retained inside. Coupled with global warming effect which already increases ambient temperature higher than normal, the level of thermal discomfort will be unbearable especially in the afternoon [1]. 
Solution by traditional mechanical system is not viable option as installing air fan will only recirculation the hot air, while using air conditioning unit is beyond economic capability. Thus, an alternative cooling system that can provide acceptable thermal comfort level and cost effective need to be identified to help the local community. Research using natural resources, which are easily available, should commence, and the proposed project will utilize circulated water as cooling agent.

\section{Heat Transfer Concept of Zinc Roofed House}

Heat transfer describes the exchange of thermal energy, between physical systems depending on the temperature and pressure, by dissipating heat. Thermal equilibrium is reached when all involved contacted bodies or the surroundings reach the same temperature. Zinc with thermal conductivity value of $116 \mathrm{~W} / \mathrm{m} . \mathrm{K}$ will efficiently absorb heat from sunlight and also efficiently release it down into the living space, primarily through conduction process. Once the zinc is heated, it will also release heat into the living space through radiation, which is a heat transfer process of transmittance. The circulated air within the living space will than add heat through convection process.

Traditional houses normally have sufficient wind driven natural ventilation, but usually lack the buoyancy driven natural ventilation to accommodate the space area above the windows level [5]. Those two factors above will contribute to the accumulation of heat inside the dwelling space. Temperatures in the range of 40 to 45 degrees Celsius in the afternoon are normal occurrence. Apart from discomfort, high temperatures are known to cause severe health hazard such as heat stroke.

\section{Research Scopes}

The objective of this research is to compare and evaluate two alternative methods that are open exhaust water and radiator system to reduce the temperature inside a zinc-roofed house. Both proposed method should be compared about the effectiveness with preferably utilized easily available resources, and should minimized use of energy.

Experiment Setup. Experiments have been run for both re-cooling system over a period at Kuikwall Centre in Universiti Tun Hussein Onn Malaysia (UTHM). Only temperature data been collected from two different rooms, where one room is selected as experimental room and will be fixed with the proposed alternative cooling method, while the other one is designated as control room and will be left intact. The effect of the factor such as airflow and humidity to temperature variation was not been considered as both rooms are deeming to be identical. Second law of thermodynamic stated that to achieve state of equilibrium, heat exchange will occur between two materials of different temperature. The direction of heat flow is from the high to lower temperature. Running lower temperature level water over higher temperature level zinc will induce the flow of heat from the letter to the former, thus lowering the zinc temperature but increasing the water temperature. By the same principles, passing heated water droplet through flowing air with ambient temperature will achieve the same effect [6].

Cooling Process Cycle. Water has been chosen to be the heat absorption agent from the zinc roof. As water filtered through the fine aperture of the perorated pipe and in contact with the flowing air, some of the droplet will be converted to finer form of mist, which is in the transient state between liquid and vapor. The conversion of material between different state (phase change ) induce heat transfer and will contribute to lowering the water temperature back to ambient level before it is re-circulated again. The system uses the concept of recirculation as the main basis process to ensure there would be no wastage of resources and environmentally friendly. Temperature difference between zinc roof and water will influence the heat exchanges. Figure 1 shows the 3D model of the overall. Figure 2 shows the system cycle of heated water cooling processes. 


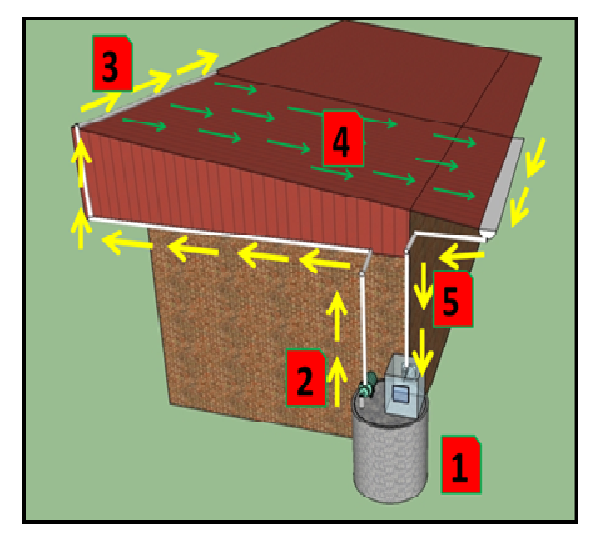

Fig. 1, Test Rig 3D Model

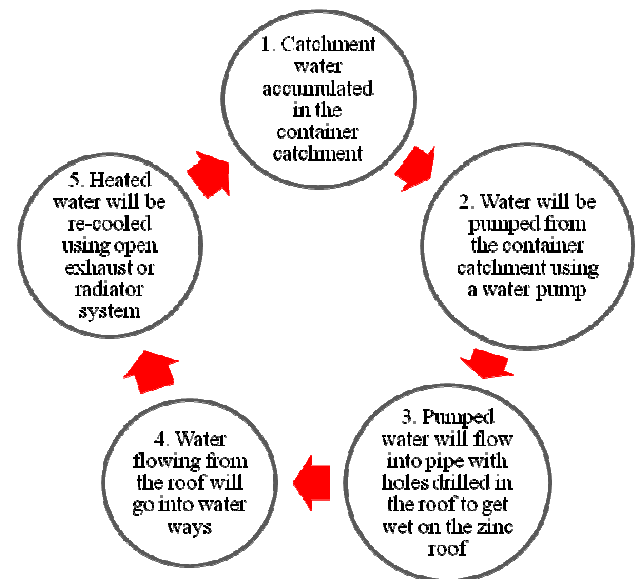

Fig. 2, Cooling process cycle

Water Re-Cooling Processes. Water that has been heated while flowing on the zinc roof will be recycled into the container to be pumped back onto the zinc roof. This project considering the temperature of the recycled water that has to be reduced to increase the temperature difference between the zinc roof and the cooling water. Two re-cooling system has been tested which are open exhaust and radiator system. This process is shown in figure 2 process number 5.

\section{Open Exhaust System}

This system converts the heated water to droplets and trickle down into the tank while blown by the cooling fan. The droplets considered to have the largest total contact area that contact with the surface (ambient temperature). The cooling fan was setup to blow the hot air around the droplets to get more temperature different yet heat exchange. Figure 3 shows the overall diagram of open exhaust system.

\section{Radiator System}

Radiator system using vehicle radiator water circulation concept of flow to cool down the temperature of heated water by lengthening the water flow path by circulate the pipes proportionally adding the time of the water to be cooled. Figure 4 shows the vehicle radiator those used as the recooling system.

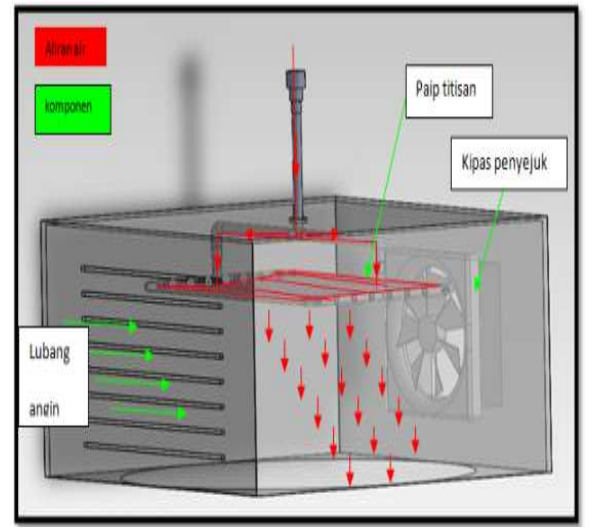

Fig. 3, Open Exhaust System

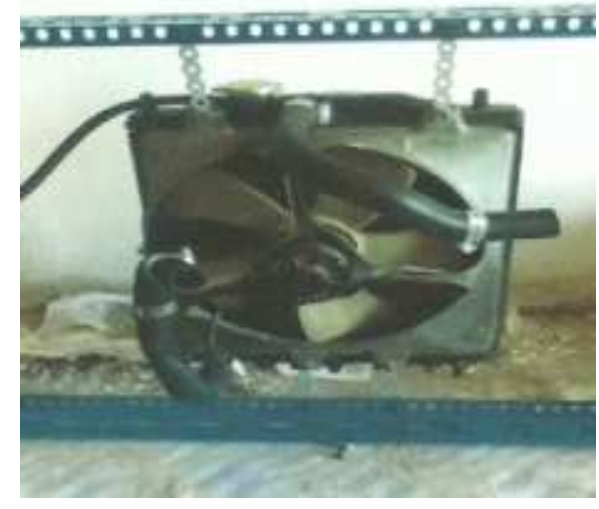

Fig. 4, Radiator System 


\section{Data Analysis and Comparison}

Tests were conducted to determine the effectiveness of the system to lower the temperature in the house. Simultaneous temperature reading from both experimental and control room are collected over a period. Both of these data were compared to determine their effectiveness. For additional reference, ambient and water temperature in collection tank were also recorded. Tests were conducted from 11 am to $3 \mathrm{pm}$ on the days when there are no sky overcast.

Comparison. Both cooling system was capable of reducing the temperature inside the house. However, in-depth study of both cooling system the pattern of cooling rate and styles are bit differs about the time required to achieve the maximum temperature delta. Figure 5 shows the radiator cooling system temperature distribution and figure 6 shows the open water cooling system temperature distribution over time (clock). The temperature delta had been compare and shown in Figure 7.

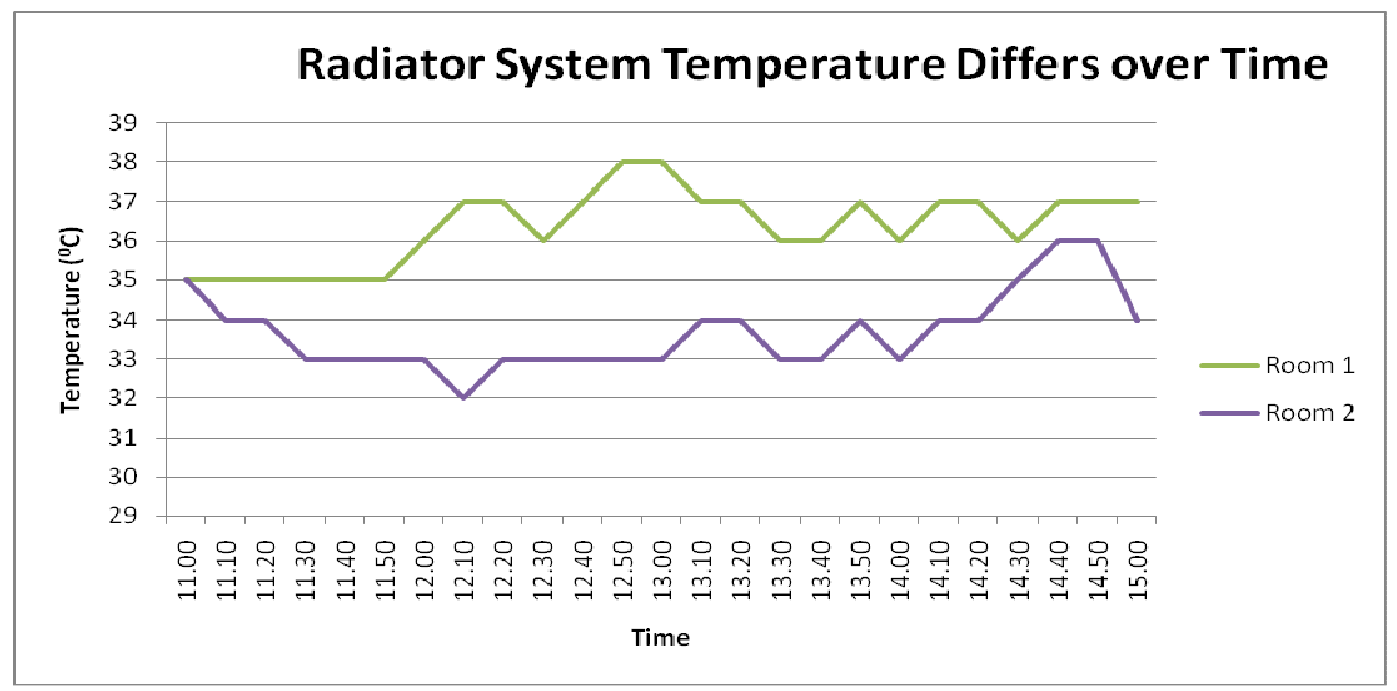

Fig.5, Radiator Cooling System Temperature Distribution

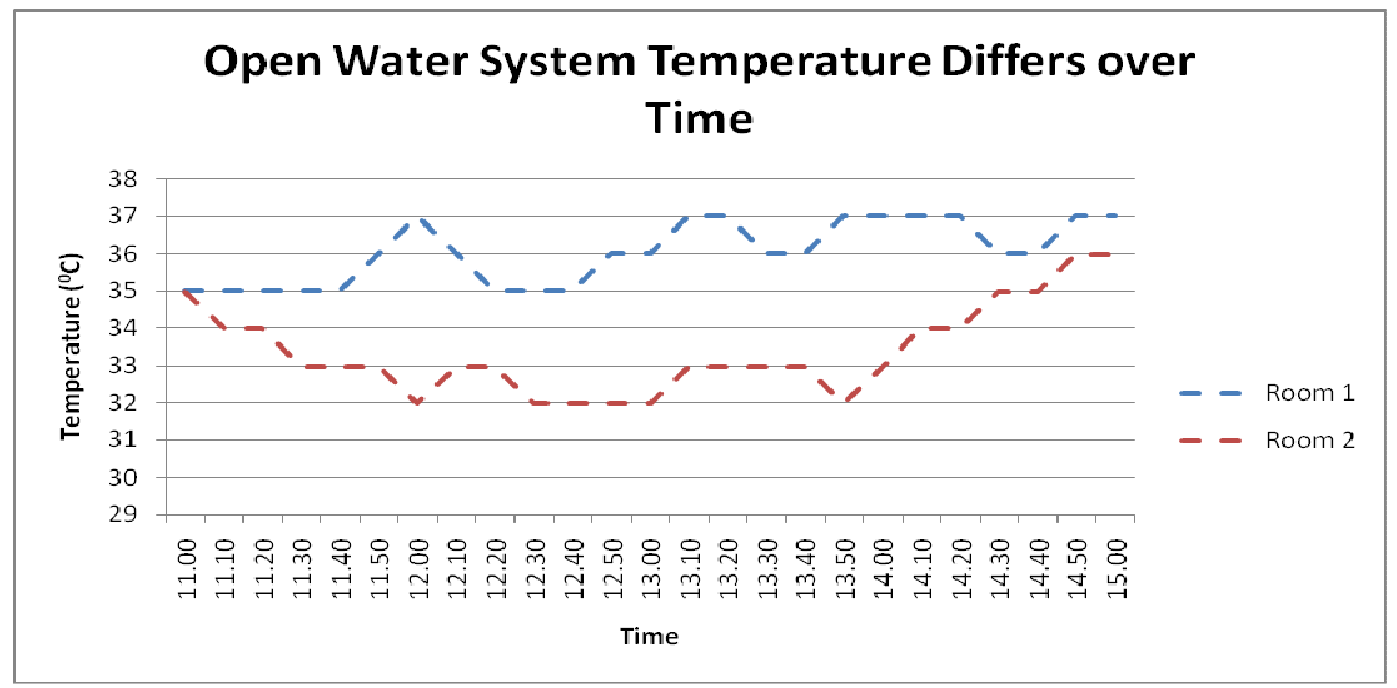

Fig. 6, Open Water Cooling System Temperature Distribution 


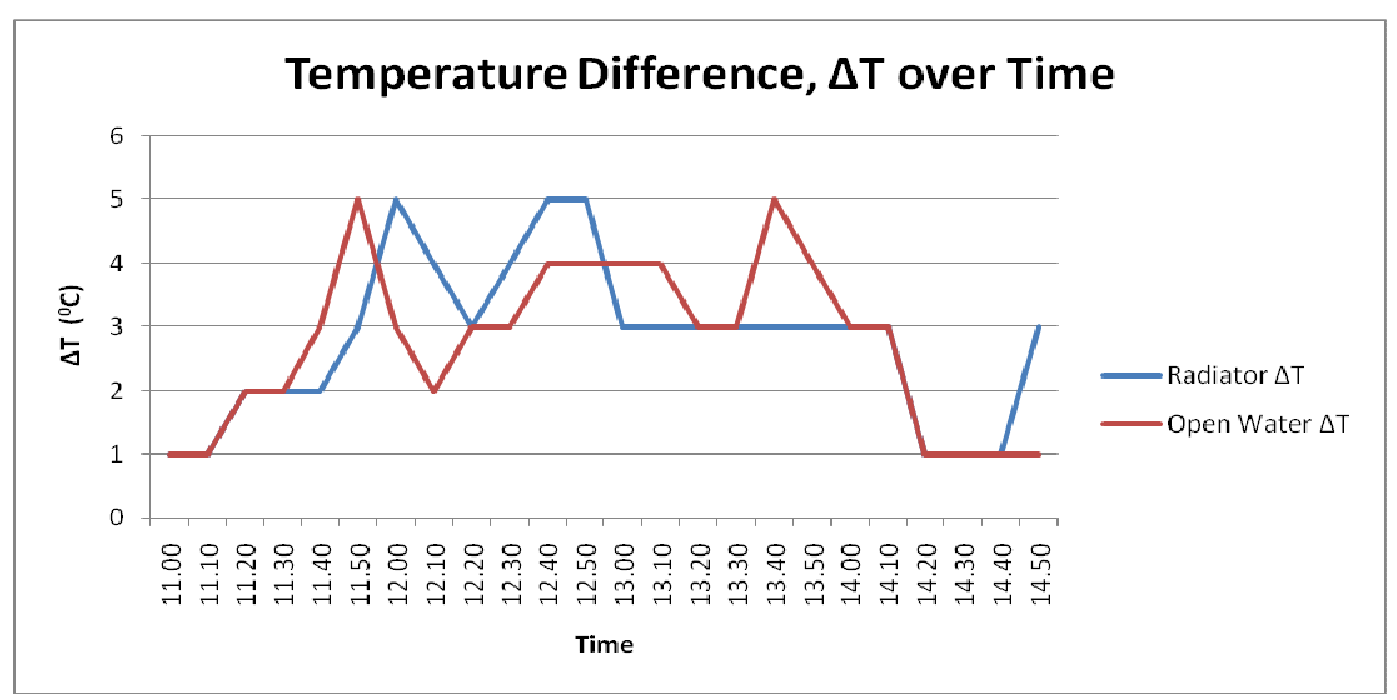

Fig. 7, Temperature Distribution Differs

\section{Summary}

Temperature pattern or trend was almost the same pattern but in Room 2 (system), it was reduced by about 5 degrees Celsius. After 2 pm (the time when the cooling system exhaust fan is shut off), the temperature in the Room 2 had increased gradually. At the same time, the temperature of the cooling water had also increased. For this pattern shown, exhaust fan could not cope with the increase of cooling water temperature. Both devices radiator and open exhaust are fluctuate with times where the system can't maintain a constant temperature in the room but both system reduce temperature in room 2.

Figure 7 shows that open water system have more fluctuated chart then radiator system that makes the system have more temperature sensitivity compare to radiator. Radiator is a system that builds in a vehicle to maintain the engine at certain temperature. This project summarize that the open exhaust re-cooling system does better cooling then the radiator considering a vehicle radiator with setup fan speed.

\section{References}

[1] Ariff M. M. (2008). "Pemanasan Global Menangani Amarah Alam". retrieved August 2013 from http://www.savesandakan.com/pemanasan-global-menangani-amarah-alam/).

[2] Mohd Yunus N. Z. (2007). Kajian Keberkesanan Saiz Tangki OSD Sebagai Sumber Guna Semula Air Hujan. Tesis Sarjana Muda, Universiti Teknologi Malaysia.

[3] Syarif Hidayat (2005) . Kajian Tentang Atap Dan Implikasinya Terhadap Keadaan Termal Rumah Sederhana Pada Iklim Panas Lembap Malaysia. Tesis Sarjana Muda, Universiti Teknologi Malaysia.

[4] Azan M. K (2007). Kegagalan Struktur Bumbung Disebabkan Oleh Beban Angin. Tesis Sarjana Muda. Universiti Teknologi Malaysia.

[5] Muhamad Azraai A. H (2007) Rekabentuk Kipas Penyejuk. Tesis Sarjana Muda. Universiti Teknikal Malaysia Melaka.

[6] Wan Mokhtar W. A. (2006) . Ramalan Aliran Haba Dan Jisim Melalui Satu Kipas Penukar Haba Menggunakan Pemodelan CFD. Tesis Sarjana Muda. Universiti Teknikal Malaysia Melaka.

[7] Amirulnizam A. (2007). Kajian Ke Atas Prestasi Sistem Penyejukan Enjin . Tesis Sarjana Muda,Universiti Teknikal Malaysia Melaka. 
[8] A. Stamou, and I Katsiris (2006). Verification of a CFD model for indoor airflow and heat transfer, Building and Environment, Vol 41, , pp. 1171-1181.

[9] J. F. Nicol, and M. A. Humphreys (2002), Adaptive thermal comfort and sustainable thermal standards for buildings, Energy and Buildings, Vol 34, pp. 5563-572.

[10] Trost, J. (1999). Heating, ventilating, and air conditioning (11 ed.).USA:Prentice. Hall.

[11] Mahmod Abd Hakim Mohamad, Masiri Kaamin, Azizul Rahman Abd Aziz, Rosdi Ab Rahman, Amir Khan Suwandi and Mohd Jahaya Kesot (2014). Kajian Kes Terhadap Sistem Penyejukan Rumah Atap Zink (SPRAZ). Prosiding Seminar Antarabangsa Kelestarian Insan 2014 (INSAN2014) Jilid 1, pp. 177-187. Pengurusan.

[12] Rosdi Ab Rahman, Masiri Kaamin, Amir Khan Suwandi, Mohd Jahaya Kesot and Norah Mohd Zan (2014). Cooling System of Zinc Roofed House by Using Circulated Water. Advanced Materials Research Vol. 935, pp. 84-87. 